\title{
SOCIAL WORK AND CHILD LAW IN SOUTH AFRICA - A LEGAL PERSPECTIVE
}

\section{Introduction and background}

The newspaper headline "Dad Loses Kids Over Lobola Debt" graced the media a year ago (28 March 2011 ILO News http://www.iol.co.za). In this case (Knowledge Kgaugelo Majola v Gauteng Department of Health and Social Development; Jabulani Place of Safety; the Minister of Safety and Security; and Cynthia Mosia, case number: 1786/11 (unreported), hereinafter "the Majola case") two toddlers were removed from the care of their father, the applicant, ten days after the burial of their mother. The basis for their removal was that their father had not rendered an amount of money outstanding towards ilobolo. The toddlers' mother died before this amount could be settled.

After removal, the children were initially placed in the care of their aunt and later moved to a state-care facility. The social worker involved informed the father that the children would not be returned to him unless he settled the outstanding ilobolo.

The court ordered the first and second respondents to return the minor children to the care and custody of the applicant (par 2).

The court ruled that the conduct by the police and the department of social services of removing the children from the care of their father was unlawful (par 4). It further ordered the social worker involved to furnish reasons why she should not be reported for unprofessional conduct (par 8). This case has triggered concerns about the responsibility carried by social workers of applying the law, specifically law relating to children, when executing their duties. This paper seeks to consider social work and the law in the light of the case highlighted above.

\section{Origins of social work}

Before embarking on the scrutiny of social workers' involvement with the law, it is appropriate to trace the origins of social work in South Africa, in order to establish how the historical background of social work influenced the present position of the profession, particularly within the South African legal system.

Social work in South Africa has an interesting evolution. It emerged from the crisis of the so-called poor-white problem. While the responsibility of providing for the needs of the poor fell on their families and respective communities, the white population enjoyed further support from churches, particularly the Nederduitse Gereformeerde Kerk (NGK) which was very active in providing welfare services. The government and charity organizations made their contributions to the poor through the church 
(Seekings "The Carnegie Commission and the Backlash against Welfare State - Building in South Africa, 1931-1937" 2008 34(3) Journal of Southern African Studies 518). The NGK was responsible, amongst other things, for the running of orphanages, homes for the elderly, farm settlements, and the administration of the child-maintenance grant (Seekings 2008 34(3) Journal of Southern African Studies 518. The child-maintenance grant was introduced in 1921). However, when the government took a resolution to launch a formal investigation on white poverty, the South African welfare system assumed a new form. The church ceased being the main role player in social welfare issues. The state began to be directly involved in the social welfare initiatives. The government mandated the Carnegie Commission of Inquiry to investigate and make recommendations on white poverty in the country. It emerged from the debates on poverty that the subject was complex and multi-faceted. Any strategy to be developed for the purposes of eradicating poverty necessitated that immediate needs of the poor be addressed, and that they be equipped to be self-sufficient economically (Seekings 2008 34(3) Journal of Southern African Studies 523). It therefore became necessary to split social welfare responsibilities between the state and the church. The state was to focus on enabling the poor to earn a living through economic measures; and the church to enforce religious and moral convictions to rehabilitate the poor (Seekings 2008 34(3) Journal of Southern African Studies 523). From this background, it can be deduced that, firstly, social work services emerged for the sole purpose of addressing the needs of white people (Mamphiswana and Noyoo "Social Work Education in a Changing Socio-Political and Economic Dispensation: Perspectives from South Africa" 2000 43(1) International Social Work 23). Secondly, the focus of social work was on poverty and related issues and did not address other social problems.

The Carnegie Commission's findings on poverty eradication were useful in shaping the social welfare system. The social welfare system became decentralized. The Commission influenced the government to fund the development of social welfare services. It also recommended that local committees, comprised of suitable persons, should be formed to carry out social welfare responsibilities (Seekings 2008 34(3) Journal of Southern African Studies 523). Although the NGK initially had control over these committees, later the control fell in the hands of the state. The committees' functions (later named social welfare committees) included collecting information, conducting intensive social work and administering some of the government-funded schemes (Seekings 2008 34(3) Journal of Southern African Studies 526). Subsequently the committees acquired the function of employing social workers (Seekings 2008 34(3) Journal of Southern African Studies 526). This is how structured social work emerged and grew over the years. (The findings of the Carnegie Commission were discussed at the National Conference on Social Work in 1936, where formal university training in social work was endorsed. See Sakaguchi and Sewpaul "A Comparison of Social Work Education Across South Africa and Japan in Relation to Global Standards for Social Work Education and Training" 200918 International Journal of Social Welfare 3).

Apartheid is a thing of the past and social work continually attempts to adapt in order to meet the needs and demands of South Africa's nation as a 
whole, and the focus is no longer limited to poverty issues, or solely to the needs of the whites (White Paper for Social Welfare (1997) Chapter 1, par 12, hereinafter "the White Paper on Social Welfare"). The White Paper for Social Welfare laid the foundation for ensuring equitable access to services. The National Development Social Welfare Strategy, as stated in the White Paper for Social Welfare, seeks to promote, amongst other things, equity, improved quality of life, transparency and accountability, accessibility and ubuntu (par 9-24). The functions of social workers have expanded and become specialized. Categories of social workers include forensic social work, clinical social work, social work in health care and social work in education (South African Council for Social Service Professions). The question that arises is: are social workers adequately trained to apply the law accurately where required?

\section{A legal framework on child law}

The South African legal framework on issues pertaining to children is quite comprehensive. A holistic approach, which considers both international and domestic laws, has to be adopted when applying the law to a particular case.

The Constitution (The Constitution of the Republic of South Africa, 1996), the White Paper on Social Welfare, legislation, civil law, indigenous African law and international instruments all form part of the said framework. Social workers, for the purposes of executing their duties on matters relating to a child, must be aware of the structure of the legal framework and the provisions of applicable laws within this framework.

Legal instruments on child care that South Africa has signed include the Convention on the Rights of the Child, ratified in 1995 and the African Charter on the Rights and Welfare of the Child, ratified in 2002. The Convention on the Rights and Welfare of the Child provides, amongst other things, that the best interests of the child shall be of primary consideration in all actions concerning children, whether undertaken by public or private social welfare institutions, courts of law, administrative authorities or legislative bodies (Article 3). The Convention on the Rights and Welfare of the Child requires state parties, where appropriate, to observe provisions of local custom, on matters affecting the child (Article 5).

The African Charter on the Rights and Welfare of the Child mandates similar rights for children as the Convention on the Rights of the Child (African Charter on the Rights and Welfare of the Child (1999)). Article 1 provides that the Charter is not permitted to affect State Party laws which are more conducive to the realization of the rights and welfare of the child. Article 25 provides that any child who is permanently or temporarily deprived of his family environment for any reason is entitled to special protection and assistance. Article 25 further provides that such child be provided with alternative care). Standards prescribed by the said instruments require enforcement of domestic laws in securing the best interests of a child. Indigenous African law is a recognized legal system in South Africa and therefore part of such domestic laws. Like any other law, indigenous African law ought to be explored and enforced for the benefit of a child whose interests are at stake. 
The White Paper on Social Welfare lays a foundation for social workers' involvement in matters relating to children. Firstly, it categorically highlights areas that require attention in the child sector. It also provides guidelines for approaches to be adopted in addressing these concerns. Secondly, it acknowledges the coexistence of civil law and indigenous African law on matters relating to children. Thirdly, it foresees that personnel training in social welfare cannot be confined to Western norms. It ought to be, amongst other things, "indigenous and culturally sensitive" (Chapter 4, par 25). It further cautions: "The urban biased training programmes should be countered. Training programmes should emphasize that urban models should not be replicated uncritically in rural contexts. Alternatives should be offered." (Chapter 4, par 25).

Section 28 of the Constitution entrenches the rights of children. This section provides that every child has the right to family care and parental care, or to appropriate alternative care when removed from the family environment (s $28(1)(b))$. It further provides that a child's best interests are of paramount importance in every matter concerning the child (s 28(2)).

The Children's Act (Act 38 of 2005), which is the primary legislation on matters relating to children, entrenches the principles of the Constitution. Further, when reading the Children's Act one can draw conclusions on the manner and extent of a social worker's involvement in matters relating to children.

Section 7 of the Children's Act reiterates the significance of considering the best interests of a child in matters affecting such child. The section further lays down factors to be considered when deciding on what is in the best interests of a child.

The Act also prescribes conditions under which children may be removed from parental care to alternative care. A person must give evidence under oath or affirmation before a presiding officer that a child who resides in the area of the children's court concerned is in need of care and protection. A child is said to be in need of care and protection if a child

(a) has been abandoned or orphaned and is without any visible means of support;

(b) displays behaviour which cannot be controlled by the parent or care-giver;

(c) lives or works on the streets or begs for a living;

(d) is addicted to a dependence-producing substance and is without any support to obtain treatment for such dependency;

(e) has been exploited or lives in circumstances that expose the child to exploitation;

(f) lives in or is exposed to circumstances which may harm that child's physical, mental or social well-being seriously;

(g) may be at risk if returned to the custody of the parent, guardian or caregiver of the child as there is reason to believe that he or she will live in or be exposed to circumstances which may harm the physical, mental or social well-being of the child seriously; 
(h) is in a state of physical neglect; or

(i) is being maltreated, abused, deliberately neglected or degraded by a parent, a care-giver, a person who has parental responsibilities and rights or a family member of the child or by a person under whose control the child is.

In these circumstances the matter will be referred to a designated social worker for investigation and the children's court will issue a court order that the said child be placed in temporary safe care (s 151(1) and (2)).

Section 152 of the Children's Act enables a social worker to remove a child to temporary safe care without a court order.

A designated social worker or a police official may remove a child to temporary care without a court order if there are reasonable grounds to believe that the child is in need of care and protection and needs immediate emergency protection (s 152(1)(a)), if the delay in obtaining a court order for the removal of a child and placing the child in temporary safe care may jeopardize the child's safety and well being (s 152(1)(b)), and where the removal of the child from his or her home environment is the best way to secure the child's safety and well-being (s 152(1)(c)).

In addition, the section echoes the need to consider what is in the best interests of the child when deciding whether a child is indeed in need of care and protection (s 152(4)).

Misuse of this section by any social worker constitutes unprofessional and improper conduct as contemplated in the Social Service Professions Act of 1978.

The legitimacy of removing a child from the care of a parent or care-giver can always be contested. The parent or care-giver can rely on the Children's Act which quantifies the sum of rights and responsibilities that parents have in respect of their children. Both in terms of the common law and the Children's Act parents who are married to each other acquire automatic parental responsibilities and rights. In terms of the common law, however, the position is different in respect of fathers who are not married to biological mothers of their children. The common law puts biological mothers of children, in comparison to unmarried fathers, in a more favourable position in respect of their children. The Children's Act changed this position. The Act affords unmarried fathers automatic parental responsibilities and rights, provided that: at the time of the child's birth he is living with the mother in a permanent lifepartnership; or regardless of whether he has lived or is living with the mother he consents to be identified or successfully applies in terms of the Act to be identified as the child's father or pays damages in terms of customary law; contributes or has attempted in good faith to contribute to the child's upbringing for a reasonable period; and contributes or has attempted in good faith to contribute towards expenses in connection with the maintenance of the child for a reasonable period (s 21(1) of the Children's Act).

According to the facts of the case at hand, the social worker removed the two toddlers from the care of their father on the basis that their father had not settled an outstanding amount of ilobolo which was due in favour of their late mother. While failure to render ilobolo does not imply endangerment of the 
children's well-being, and therefore does not constitute a ground for the removal of the children to a place of safety, it does, however, raise the following questions: Firstly, what is the legal status of the relationship between the toddlers' father and their late mother if ilobolo has not been rendered in full? Secondly, whether or not the children should remain in the care of their father even though ilobolo has not been rendered in full? This, in turn, calls for the examination of the relevance of indigenous African law in this case, over and above the provisions of the Constitution and the Children's Act. After all, section 211 of the Constitution provides that the courts must apply indigenous African law when that law is applicable, subject to the Constitution and any legislation that specifically deals with customary law.

Undoubtedly, for the social worker to make an optimal decision on whether or not to remove the toddlers from the care of their father, the legal framework, as stated above, had to be relied upon.

\section{Application of the law}

In applying the tenets of the law, it is apparent that the social worker made an error in judgment by removing the two toddlers from the care of their father. Social services removed the two toddlers from the care of their father and placed them in the care of an aunt, with whom they were not familiar. They were later moved to a further unfamiliar environment, a state facility, where they resided until they were returned to their father's care.

Firstly, the main principle of considering the best interests of a child, as entrenched in the Constitution and expounded in Children's Act, was not observed. Secondly, the toddlers were not in need of care and protection and therefore did not qualify for removal from the care of their father. Thirdly, the removal of the toddlers violated the father's rights as provided in section 21(1) of the Children's Act, namely, his parental responsibilities and rights. Lastly, such removal had no basis even in terms of indigenous African law.

If one were to assume that indigenous African law was the basis for the social worker's decision to remove the toddlers from the care of their father, clearly the social worker's comprehension of the indigenous African law was also not accurate. In indigenous African law, provisions relating to acquiring parental responsibilities and rights are similar to those stipulated in the Children's Act. In terms of indigenous African law an unmarried father acquires parental responsibilities and rights when he pays damages (the term damages is used collectively to refer to various types of damages in indigenous African law including: inhlawulo and imvimba beast) in respect of his child. As soon as damages are paid the man becomes entitled to access, custody and/or guardianship in respect of his child (Mofokeng Legal Pluralism in South Africa: Aspects of African Customary, Muslim and Hindu Family Law (2009) 102-103).

The concept ilobolo is broad when viewed from the perspective of acquiring parental responsibilities and rights. The said damages are part of ilobolo. Therefore irrespective of whether ilobolo has be rendered in full or not, when a man has paid damages in respect of his child, he acquires parental responsibilities and rights in respect of that child (Mofokeng Legal Pluralism in 
South Africa 102-103). Unless damages are paid, the parental responsibilities and rights in respect of the child remain with his or her maternal family (Mofokeng Legal Pluralism in South Africa 103-104).

A flip side to this discussion is that in terms of the "living" indigenous African law, ilobolo determines the identity of the child. If ilobolo has been rendered, the child belongs to the man's family. If not rendered, the child belongs to the woman's family. Of course this is a very simplistic way of looking at the issue. Our laws have evolved and have become more complex. Decisions on matters affecting children should be guided first and foremost by the dictates of the Constitution and other applicable laws, viewed in a holistic manner. Regardless of the angle from which the social worker's reasoning is viewed, his application of the law was incorrect.

\section{Conclusion}

This case required a social worker to have a comprehensive understanding of the South African legal system in order to arrive at some conclusion which is legally acceptable for the removal of the toddlers from the care of their father. Can it really be expected of social workers to possess such a complex comprehension of the law when executing their duties?

While it is expected of social workers to understand the legal system (Madden "Legal Content in Social Work Education: Preparing Students in Interprofessional Practice" 2000 20(1/2) Journal of Teaching in Social Work 5) a reasonable response to this question is still "no". The training that social workers receive does not warrant social workers to be able to synthesize the law at the level that this calls for. Social workers are not legal practitioners. Law is not a core component to their training. The irony, however, is that law does seem to be becoming more and more a core component in their field of work.

Some scholars have suggested that for social workers to be able to perform at their optimal level when dealing with legal issues, they should collaborate with legal practitioners (Madden 2000 20(1/2) Journal of Teaching in Social Work 5). Ideally, that should be the case. At a simplistic level, social workers may rely on legal practitioners for consultation purposes. However, meaningful collaboration call for more than mere consultation processes. It requires communication, joint planning and intensive negotiations in the interests of the client (Weil "Research on Issues in Collaboration between Social Workers and Lawyers" 1982 56(3) Social Service Review 395). Extensive collaboration is further necessitated by the fact the two different professions will have to find a common point of departure in order to execute their duties. Such a point of departure cannot be properly established through superficial and simplistic consultation processes. Meaningful collaboration is unfortunately bound to exacerbate delays in service delivery. The collaboration process is also likely to be costly for government departments as collaboration would require more manpower. 